NBER WORKING PAPER SERIES

\title{
EXCHANGE RATES AND CASUALTIES \\ DURING THE FIRST WORLD WAR
}

\author{
George J. Hall \\ Working Paper 9261 \\ http://www.nber.org/papers/w9261 \\ NATIONAL BUREAU OF ECONOMIC RESEARCH \\ 1050 Massachusetts Avenue \\ Cambridge, MA 02138 \\ October 2002
}

I thank Michael Bordo, William Brainard, Timothy Guinnane, Lingfeng Li, Thomas Sargent, and Mark Watson for helpful conversations. I thank Richard Burdekin, Marc Weidenmier, and seminar participants at Yale and Rutgers for constructive comments. The views expressed herein are those of the author and not necessarily those of the National Bureau of Economic Research.

(C) 2002 by George J. Hall. All rights reserved. Short sections of text, not to exceed two paragraphs, may be quoted without explicit permission provided that full credit, including (C) notice, is given to the source. 
Exchange Rates and Casualties During the First World War

George J. Hall

NBER Working Paper No. 9261

October 2002

JEL No. N1, E4

\begin{abstract}
I estimate two factor models of Swiss exchange rates during the FirstWorldWar. I have data for five of the primary belligerents: Britain, France, Italy, Germany, and Austria-Hungary. At the outbreak of the war, these nations suspended convertibility of their currencies into gold with the promise that after the war each would restore convertibility at the old par. However, once convertibility was suspended, the value of each currency depended on the outcome of the war. I decompose exchange rate movements into a common trend, a common factor, and country-specific factors. Movements in the common trend are consistent with the quantity theory of money. The common factor contains information on contemporaries' expectations about the war's resolution. Innovations to this common factor are correlated with time series on soldiers killed, wounded, and taken prisoner.
\end{abstract}

George J. Hall

Department of Economics

Yale University

P.O. Box 208268

New Haven, CT 06520-8268

and NBER

e-mail: george.hall@yale.edu 


\section{Introduction}

Throughout World War I, Switzerland, a neutral country, traded with both sides of the conflict. Consequently the Swiss franc was actively traded throughout the war in foreign exchange markets in Basle, Paris, London, and Berlin. Price data on the currencies of five belligerent nations indicate that while these governments tried to influence the value of their currencies during the war, they were not entirely successful. As the war progressed their ability to manipulate currency markets declined, and the value of their currencies relative to the Swiss franc fell. While this relative decrease in currency values can be attributed to differences in money growth rates, it also appears that the value of the belligerents' currencies fluctuated with military news. In particular, good war news for the Allies increased the value of the Allied currencies relative to the currencies of the Central Powers and vice versa.

To formalize these observations, I construct and estimate two factor models. On the Allied side I have data on the British, French, and Italian rates. Of the Central Powers, I have data on German and Austro-Hungarian exchange rates. Since I have data on both Central and Allied countries, I can decompose movements in currency prices into movement due to a common trend, movements due to a common factor, and movements due to country-specific factors. Consistent with the quantity theory of money, the common trend is highly correlated with a common trend in the money stocks of the belligerent countries. The common factor, on the other hand, rises with good news for the Allies and falls with good news for the Central Powers. I interpret this common factor as a measure of contemporaries' expectations of the war's outcome.

Using time series on casualties from the Western Front, I compute a "net body count" by subtracting the number of Germans killed and wounded from the number of British killed and wounded. I also compute a "net POWs" series by subtracting the number of Germans taken prisoner from the number of British taken prisoner. Innovations to the common factor are positively correlated with the net body count series and negatively correlated with the net POWs series. Since offensive campaigns usually resulted in less favorable net body counts, these correlations suggest that being on the offensive was viewed positively by financial markets. The negative correlation between net POWs and innovations to the common factor suggests that the number of soldiers taken prisoner is a proxy for morale and the willingness of soldiers to continue fighting. Taken together, these findings support the view expressed by Niall Ferguson in his 1998 book The Pity of War that the key to victory in the First World War was not directly due to ones' ability to kill and wound the enemy, but rather due to the willingness of the enemy to surrender. 
Traditionally during times of war, governments induced money- and bond-holding by promising, contingent on winning the war, postwar deflation. Bordo and Kydland (1995) argue that the gold standard, as practiced from 1880 to 1914 , represented a state-contingent policy rule. During calm periods, each government on the gold standard kept the value of its currency fixed in terms of gold. But in the event of a well understood, exogenously produced crisis, such as a war, gold convertibility could be suspended with the understanding that, after the crisis had safely passed, convertibility would be restored at the old par. During the crisis, the government could issue paper money and sell debt to meet its short-term spending needs; but in doing so, it had to commit (either explicitly or implicitly) to eventually pay off this new debt in gold. Implicit in this policy rule is that after the resolution of the crisis, the government commits to undertake deflationary policies sufficient to return to the gold standard at the original parity.

This state-contingent policy was carried out by Britain in the Napoleonic Wars and to some extent by both sides in the American Civil War. ${ }^{1}$ During the U.S. Civil War, both sides promised to carry out this state-contingent policy; however after the war, only the Union was able to honor its commitments. The Union was on the gold standard prior to the outbreak of the Civil War. During the hostilities the Union suspended specie payments and issued an unbacked currency, the greenback; this led to an increase in the money supply and a 70 percent rise in the price level during the war. Despite substantial political opposition, the U.S. undertook deflationary policies after the war and returned to convertibility at the prewar parity in 1879. The Confederacy attempted to carry out a similar policy. It issued non-interest bearing notes (the graybacks) that specified a date that the government promised to redeem the obligations for gold. Of course, by the conclusion of the war the Confederate government could not honor its commitments, and these notes were worthless.

During the First World War, governments on both sides promised, contingent on winning the war, to restore convertibility at the old par; however, despite all of the belligerent governments surviving the war (unlike the U.S. Confederacy), several governments could not afford to (or chose not to) implement postwar deflation sufficient to restore the old par. While Britain, Switzerland, and several Scandinavian countries (Denmark, Norway, and Sweden) resumed convertibility at the original par by 1925, France and Italy chose to resume convertibility at new lower level of par. Germany, as well as the newly formed nations of Austria and Hungary, made no attempt to return to the gold standard after the war but instead engineered

\footnotetext{
${ }^{1}$ See Bordo and White (1991) for a description of British debt management polices during the eighteenth and early nineteenth centuries. Bordo and White argue that Britain's fiscal and monetary policies were consistent with Barro's (1979) tax smoothing model with non-state contingent debt. I interpret changes in the price level as the mechanism Britain used to incorporate statecontingencies into its debt. See in particular figure 8.9 of Bordo and White.
} 
a hyperinflation. Through this policy of hyperinflation, the German government effectively defaulted on its nominal obligations and convinced the Allies to reduce the required reparation payments. If all governments were expected to return to their old pars soon after the war, currency values would simply be a function of the expected duration of the war. However, during World War I many contemporaries believed that much of the costs would be paid by the losers. The issue of reparations is one potential contributing factor in leading the Allied and Central Power currencies to move in opposite directions.

Germany at the end of the Franco-Prussian War, in 1871, had imposed a large indemnity on France and hoped to do the same at the end of this war. Indeed throughout the war Germany made only modest attempts to finance its wartime expenditures through taxation and thus depended almost solely on loans to finance its military. ${ }^{2}$ While the German government hoped to avoid the inefficiencies of additional direct distortionary taxation of its citizenry during the war, it believed it would be able to shift its costs onto Britain and France after the war. Dr. Karl Helfferich, Minister of Finance of the German government stated on March 10, 1915:

The Federated Governments ... believe that they should not aggravate the already heavy burden of the war by new taxes or increases of taxes. ... We have a firm hope that after the conclusion of peace we shall present to our opponents a bill for the expenses of the war forced upon us. (Bogart, 1921 and Kuczynski, 1923)

On August 20, 1915 he went on to say:

We do not wish to increase by taxation during the war the tremendous burden which our people bear, so long as there is no compelling necessity. ... As things are, the only method seems to be to leave the settlement of the war bill to the conclusion of peace, and the time after peace has been concluded. And on this I would say: If God grant us victory and with it the possibility of moulding the peace to suit our needs, we neither can nor will forget the question of costs. We owe that to the future of our people. The whole course of the future development of their lives must, if at all possible, be freed from the appalling burden caused by the war. Those who provoked the war, and not we, deserve to drag through the centuries to come the leaden weight of these milliards.(Bogart, 1921 and Kuczynski, 1923)

This view was not uniquely held by the Central Powers.

Although the Allies used taxation to cover a larger share of their war expense than the Central Powers, there was little doubt during the last two years of the war that the Central Powers (particularly Germany)

\footnotetext{
${ }^{2}$ See Kuczynski (1923) for a detailed discussion of German tax policy during the war. Interestingly, Kuczynski argues that German fiscal policy was designed to cover expenses of the "peace budget, excluding army and navy" and the interest on war debt through taxation and to cover the expenses of the "peace budget for army and navy" and the wartime expenditures through debt. These intentions are consistent with the optimal tax smoothing policy implied by Barro (1979). The Germans were unsuccessful in carrying out this policy and much of the interest on the war debt was covered by new loans.
} 
were expected to pay the bill for the damage caused by the war. ${ }^{3}$ The Allies had repeatedly stated that their objectives in the war included "the restoration of Belgium, of Serbia, and of Montenegro, and the indemnities that are due them; the evacuation of the invaded territories of France, of Russia, and of Roumania with just reparation.” (Burnett, 1965, Document 5, Reply of the Allies to Wilson, January 10, 1917.)

Even without the possibility of reparations, once off the gold standard each currency became a contingent claim that depended on the likelihood and timing of the country's return to the gold standard at the old par. Restrictions imposed by the government budget constraint required the value of these obligations to depend not only on the quantity outstanding but also on the expected discounted present value of the future stream of primary surpluses. Hence as traders learned about the war's length and costs, forecasts of future government surpluses for the belligerents would generally move together; it follows that the value of all the belligerents' currencies should move together. However with the possibility of reparations, the expected value of future primary surpluses depended critically on winning or losing the war. Thus the government's ability to resume convertibility at the old par depended not only on when but also how the war would end. One would expect that the value of Allied currencies would at times move in opposite directions to those of the Central Powers. If this is the case, the value of these nominal government obligations provide information about contemporaries' expectations of the duration and resolution of the war.

The idea that war news influences the value of a nation's currency and other claims on the government is an old one. In 1903 Wesley Mitchell argued that many of the rapid and violent movements in the value of the Greenback during the U.S. Civil War could not be explained by changes in the volume of money outstanding as the quantity theory of money would predict; instead, many of these movements were the result of news from the battlefield. Likewise, Roll (1972) documents that during the Civil War federal bond prices and thus interest rates were also a function of war news. More recently Willard, Guinnane, and Rosen (1996) study daily price data for U.S. Greenbacks from the New York gold market. They employ a purely statistical method to distinguish between events that have long-lived effects on prices ("turning points") and those events that simply generated "blips" in the data. Brown and Burdekin (2000) apply Willard, Guinnane, and Rosen's methodology to price data on Confederate bonds traded in Europe. These studies use data from one side of the war. But war is (at least) a two-sided activity, so it is useful to incorporate data from all sides. McCandless (1996) estimates a single-factor model for the U.S. Civil War using data on gold prices from both the Union and Confederacy. Weidenmier (1999) uses both Confederate

\footnotetext{
${ }^{3}$ Kuczynski (1923) reports that the tax revenue available to Great Britain for wartime expenditures was three times as high as in Germany.
} 
and Union currency prices to test the hypotheses that the Union was fighting to win while the Confederacy was only fighting for a draw. Frey and Kucher (1997) use Willard, Guinnane, and Rosen's methodology to study the prices of German, Austrian, French, Belgian, and Swiss government bonds traded in Switzerland during World War II, though they analyze each of these countries individually.

Most of the papers cited in the previous paragraph follow Wesley Mitchell and ask whether battlefield news or the quantity theory of money is the primary determinant of currency prices during a war. I take a different approach by decomposing the changes in currency values into three components. I find that movements in the first component, a common trend, are consistent with quantity theory of money. Movements in the second component, a common factor, are correlated with news from the battlefield. Thus for the exchange rate data I study these two explanations are not mutually exclusive.

\section{The Exchange Rate Data}

I collected daily and monthly data on Swiss exchange rates during the war. Daily exchange rates from January 4, 1916 to November 30, 1918 are from three separate sources. The British-Swiss exchange rates, taken from the London Times, are the average of the high and low trading prices on the London Course of Exchange. The French-Swiss exchange rates, taken from Le Petit Parisien, are the average of the bid and ask prices from the Paris bourse. The German-Swiss exchange rates from January 1916 to November 1918 were provided by the Deutsche Bundesbank; they are the average exchange rate in Berlin. The monthly exchange rate data are taken from Appendix VIII of the Swiss Bank Corporation report, Revue Commerciale et Industrielle Suisse, 1914-1918 published in 1919. The data are monthly averages of the offer and demand quotations for sight drafts on the British pound, French franc, Italian lira, German mark, and Austrian-Hungarian kronen at the Basle bourse from July 1914 to November 1918.

The theory discussed in the introduction suggests that currency holders would be more concerned with the price of gold than with price of the Swiss franc. I am assuming the price of the Swiss franc in terms of the belligerent currency multiplied by the price of gold in terms of the Swiss franc is equal to the price of gold in terms of the belligerent currency. I would prefer to study data on the market price of gold in terms of each one of these five currencies. Unfortunately, I was unable to find any reliable series on the market price of gold. For example, the Bundesbank reported in a personal correspondence that the official price of gold in terms of marks was unchanged at 1 Kilogram $=2790$ Marks from 1914-1918.

Prior to the war, all five belligerent countries were either explicitly on the gold standard or had a policy 
of keeping the value of their currency near the nominal par. By August of 1914, all five of these belligerent countries had effectively suspended convertibility of their currency into gold and placed restrictions on the exportation of gold. All of the belligerent nations attempted to maintain stable exchange rates. The most effective of the stabilization policies was carried out by the Allies. In April 1916 the French and British governments agreed to stabilize the franc-sterling exchange rate through gold exports from France to Britain and loans. During this time, the sterling-dollar exchange rate was also stabilized, so the relative prices of US, French, and British currency were effectively fixed for the remainder of the war. In the summer of 1918 Italy made various agreements with the United States, Great Britain, and France to enter into the Allies fixed exchange rate agreement.

While the Allies were eventually successful in their attempts to fix the intra-Allied exchange rates, the Central Powers were less so. During the first week of war, Germany went off the gold standard and almost immediately engaged in a policy of using short-term domestic credit to finance its war effort. While Germany was able from time to time to obtain some loans from Switzerland and the Scandinavian countries, it had substantial trouble obtaining long-term loans from foreign sources. As sources of credit started to run out, the German and Austrian governments tried several times to stabilize its exchange rates by setting up consortiums of banks to carry out all foreign exchange transactions at fixed rates. Nevertheless, as the war progressed, these consortiums were unable to maintain the value of the mark and kronen due to a lack of funds.

Several features of the gold standard remained intact for the duration for the war. The definition of the gold content of the standard coins remained unchanged. The central banks and treasuries continued to honor their obligations to purchase gold at the fixed mint prices, and no restrictions were placed on the import of gold. Nevertheless, the existence of these consortiums and controls suggests that the war period was one of fixed prices. However, while some of these exchange rates were fixed successfully (e.g. the dollar-sterling-French franc), others were less successful. Maintaining fixed exchange rates is expensive. As the war progressed, the belligerents became poorer, and their ability and willingness to maintain their exchange rates declined. All of these currencies fell in value relative to the primary neutral nations, Switzerland, Sweden, Denmark, and Spain.

I do not have data on the volume of trades that took place in any of the four foreign exchange markets from which I have price data. However, there is evidence that foreign exchange was a relatively thick, liquid market in Switzerland during the war. The Swiss Bank Corporation (1919) states that during the war "In Switzerland, in Holland, and the Scandinavian countries, the operations in foreign exchange have taken 


\begin{tabular}{||ll|c|c|c|c|c|c||}
\hline country & & 1913 & 1914 & 1915 & 1916 & 1917 & 1918 \\
\hline Great Britain & imports & 113 & 76 & 112 & 160 & 269 & 248 \\
& exports & 236 & 234 & 355 & 424 & 362 & 269 \\
France & imports & 348 & 221 & 189 & 236 & 305 & 208 \\
& exports & 141 & 115 & 220 & 401 & 462 & 466 \\
Italy & imports & 207 & 194 & 259 & 390 & 369 & 222 \\
Austria-Hungary & exports & 91 & 89 & 89 & 150 & 136 & 97 \\
& imports & 109 & 103 & 66 & 45 & 44 & 61 \\
Germany & exports & 78 & 67 & 157 & 195 & 93 & 101 \\
& imports & 631 & 481 & 418 & 472 & 483 & 619 \\
& exports & 306 & 274 & 457 & 709 & 698 & 445 \\
\hline
\end{tabular}

Table 1: Swiss imports from and exports to each of the five belligerents, 1913-1918, in millions of nominal Swiss Francs.

Source: Swiss Bank Corporation, (1920) La Situation Economique et Financiere de la Suisse: 1919, page 36.

on an unaccustomed, and surely temporary, importance." Both the Swiss Bank Corporation (1918) and the Federal Reserve Bulletin (1918) report that "Owing to its central geographic position, foreign exchange rates in Switzerland have come to be regarded as on the whole the most reliable basis for international comparisons." ${ }^{4}$ Brown (1940, pages 13-14) reports that after the outbreak of the war "Remittance between the Central Powers and the Allied world continued to be made, though with difficulty, through markets of Germany's neutral neighbors. The Swiss foreign exchange market in particular became extremely important in the world economy for this reason ..."

Switzerland actively traded with both the Central and Allied countries. Table 1 shows that the Swiss traded roughly equal amounts with both sides throughout the war. While exports and imports fell at the outbreak of hostilities, as the war progressed trade with the belligerents increased. Multiplying each number in table 1 by 4.25 provides a rough estimate of the magnitude in 2001 U.S. dollars of Swiss trade with each of the belligerents. ${ }^{5}$ In 1915 Switzerland imported about $\$ 1.8$ billion worth of goods (in 2001 dollars) from Germany and exported about $\$ 950$ million worth of goods to France. Young (1925) also reports that Swiss private investors bought considerable amounts of foreign securities. This level of trade would support a sufficiently large volume of foreign exchange to ensure that the rate data I study are meaningful. Finally, I have exchange rate data from three other neutral countries: Denmark, Sweden, and

\footnotetext{
${ }^{4}$ The quote is taken from the Federal Reserve Bulletin (May 1, 1918, page 390) though it appears to have been translated directly from page 63 of the Swiss Bank Corporation (1918) Revue Economique et Financiere Suisse.

${ }^{5}$ During this time period, one Swiss franc was worth between 20 and 25 U.S. cents. One U.S. dollar in 1915 is equivalent to $\$ 17.50$ in 2001.
} 


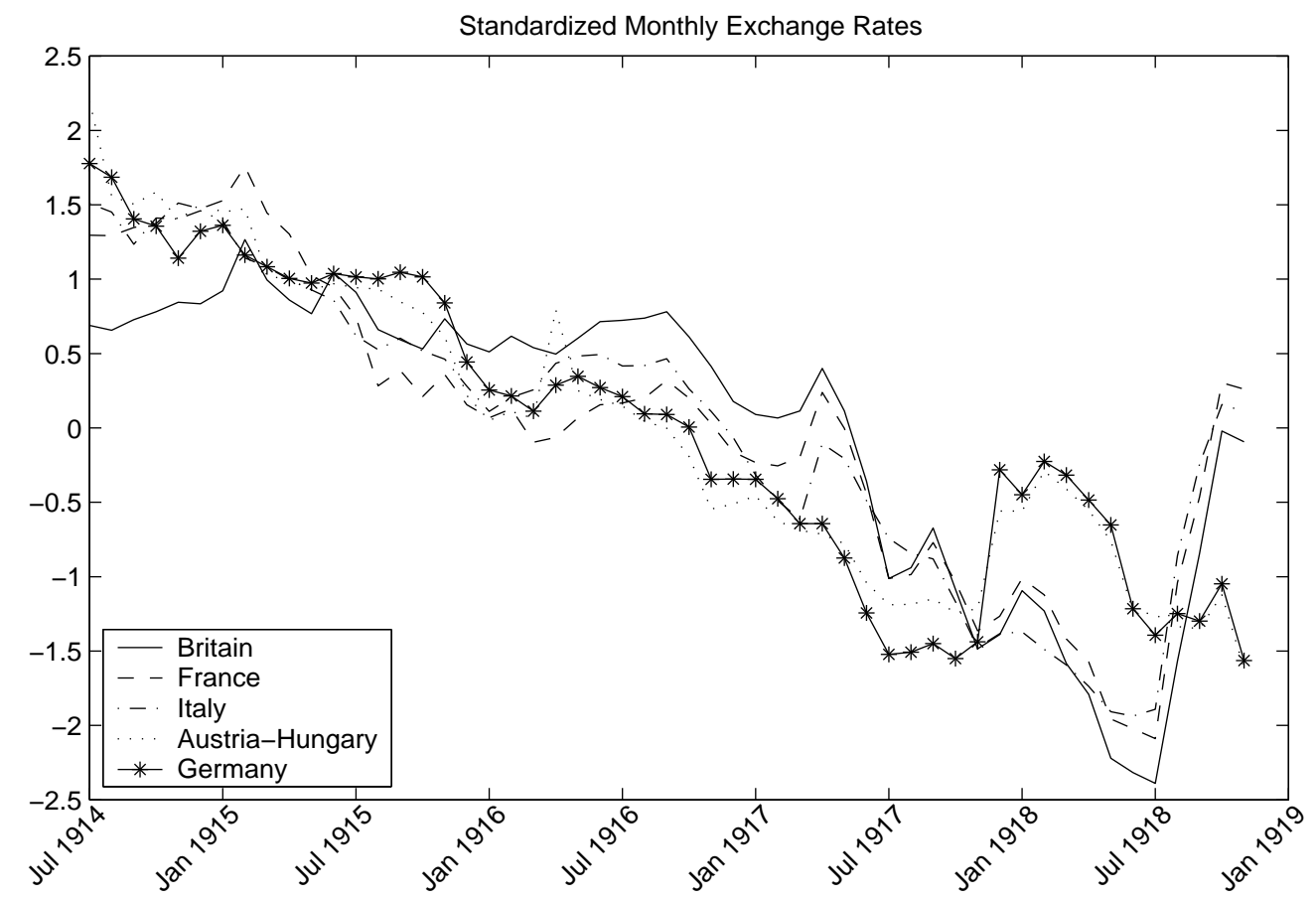

Figure 1: Monthly exchange rates normalized to have a mean of zero and a standard deviation of one.

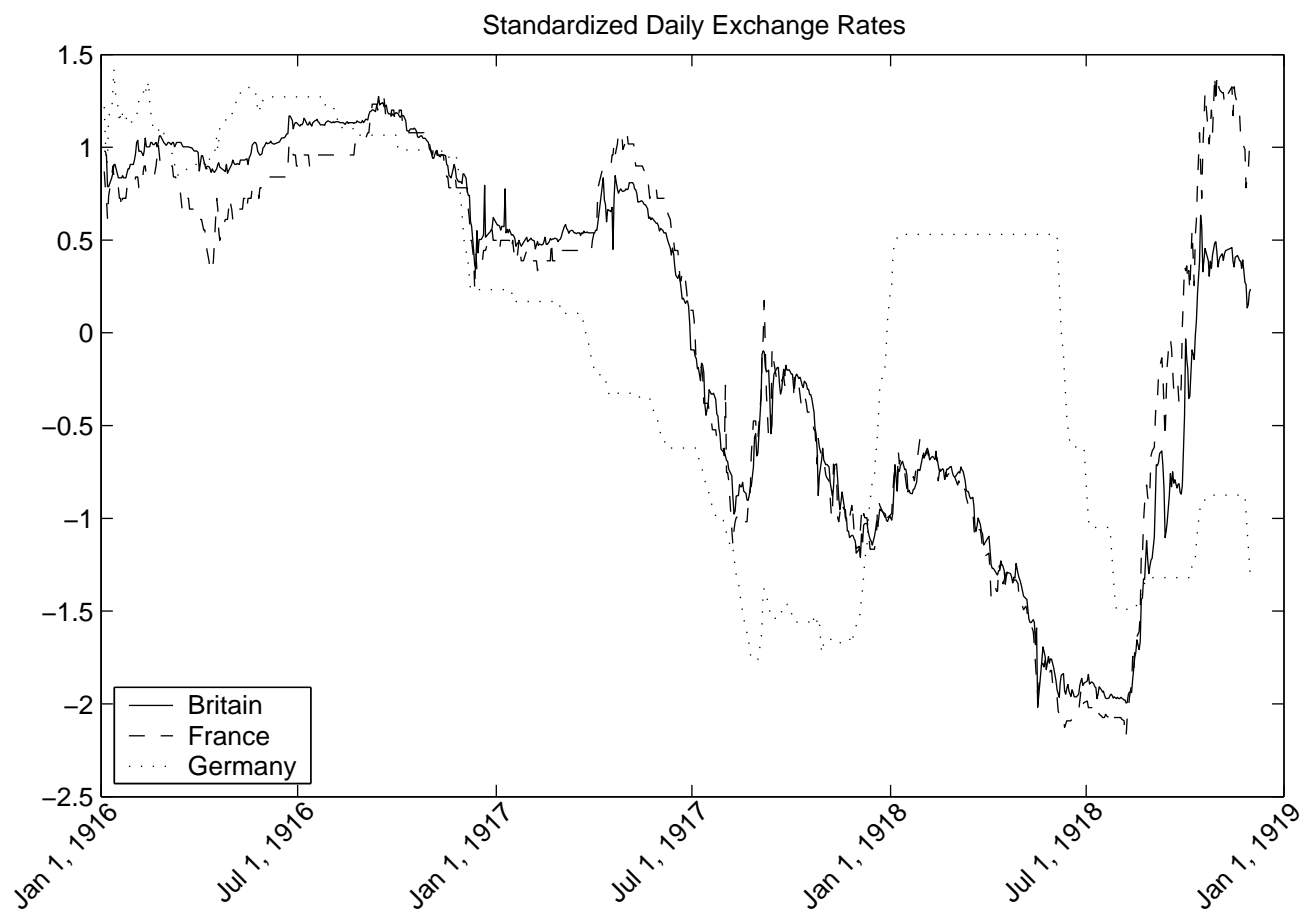

Figure 2: Daily exchange rates normalized to have a mean of zero and a standard deviation of one. 
Spain. These exchange rates display qualitatively similar time series patterns to the Swiss rates. I focus on the Swiss franc because my two Swiss datasets are the most complete ones I have and the above quotes convinced me that the Swiss market was the primary exchange market during the war.

Since each of the exchange rates are in different units, I subtracted the mean from each series and divided each series by its standard deviation. Thus $\frac{1}{T-1} Y^{\prime} Y$ is the matrix of correlation coefficients of the normalized exchange rates where $T$ is number of observations per series, and $Y$ is a $T \times 5$ or $T \times 3$ matrix of the normalized series. These normalized series are plotted in figures 1 and 2. The dominant feature of these figures is the steady decline of all the currencies against the Swiss franc. The belligerents made repeated efforts to maintain the value of their currencies; but eventhough the Swiss price level more than doubled during the war, they could not maintain the value of their currencies relative to the Swiss franc.

For three reasons most of my analysis focuses on the monthly data. First, each of the monthly rates are the price of a Swiss franc in Basle, while the daily dataset reports the prices of a Swiss franc in Berlin, London, or Paris. Given the events of the time, it is not obvious that one could arbitrage across these three markets. Second, the monthly dataset has prices for five currencies whereas the daily dataset only has prices for only three. Third and most importantly, the market for Swiss francs in Berlin does not appear to have been a free market. As can be seen in figure 2, prices for Swiss francs in Berlin remained unchanged for long periods of time. I would prefer to have constructed a daily dataset of exchange rates from the Basle market (or some other neutral country that traded with both sides), but I could not find a source that reported daily rates from this market (or the other neutral markets) consistently throughout the war.

\section{The Factor Model}

The factor model consists of four equations. ${ }^{6}$ Let $y_{t}$ denote the $5 \times 1$ vector of time $t$ exchange rates: $y_{t}=\left[y_{t}^{\text {Britain }}, y_{t}^{\text {France }}, y_{t}^{\text {Italy }}, y_{t}^{\text {Germany }}, y_{t}^{\text {Austria }}\right]^{\prime}$. Each element of $y$ is a linear function of a common trend, $f, a$ common factor, $z$, and a country-specific factor $v^{i}$ :

$$
y_{t}^{i}=f_{t}+\gamma_{i} z_{t}+v_{t}^{i}
$$

for $i=\{$ Britain, France, Italy, Germany, Austria $\}$. I assume the common trend is an $\mathrm{I}(2)$ process:

$$
f_{t+1}-f_{t}=f_{t}-f_{t-1}+\varepsilon_{t+1}
$$

where $\left\{\varepsilon_{t}\right\}$ is a sequence of i.i.d. normal random variables with a mean of zero and a variance of $\sigma_{\varepsilon}^{2}$.

\footnotetext{
${ }^{6}$ I present only the five-country monthly model. The three-country daily model only differs in the number of countries.
} 
Let $z_{t}$ denote the common factor at time $t$. I assume $z_{t}$ follows the first-order auto-regression,

$$
z_{t+1}=\rho z_{t}+\vartheta_{t+1}
$$

where $0<\rho<1$ and $\left\{\vartheta_{t}\right\}$ is a sequence of i.i.d. normal random variables, uncorrelated with $\varepsilon_{t}$ at all leads and lags, with mean zero and variance one. Let $\left\{\mathrm{v}_{t}\right\}$ denote the $5 \times 1$ vector of country-specific factors. I assume each country-specific factor is serially correlated:

$$
\mathrm{v}_{t}=D \mathrm{v}_{t-1}+\eta_{t}
$$

where

$$
D=\left[\begin{array}{ccccc}
d_{\text {Britain }} & 0 & 0 & 0 & 0 \\
0 & d_{\text {France }} & 0 & 0 & 0 \\
0 & 0 & d_{\text {Italy }} & 0 & 0 \\
0 & 0 & 0 & d_{\text {Germany }} & 0 \\
0 & 0 & 0 & 0 & d_{\text {Austria }}
\end{array}\right]
$$

and $\eta_{t}$ is a $5 \times 1$ vector of martingale differences sequences whose elements satisfy

$$
\begin{aligned}
E \eta_{t}^{i} \eta_{s}^{j^{\prime}} & = \begin{cases}r_{i} & \text { if } t=s \text { and } i=j \\
0 & \text { otherwise }\end{cases} \\
E \eta_{t} \vartheta_{s} & =0 \forall t \text { and } s \\
E \eta_{t} \varepsilon_{s} & =0 \forall t \text { and } s
\end{aligned}
$$

for $i$ and $j$ equal to Britain, France, Italy, Germany, Austria\}. Let $R$ denote a $5 \times 5$ diagonal matrix with the elements $r_{i}$ along the diagonal. Finally $\theta$ denotes the $1 \times p$ vector of parameters to be estimated: $\theta=$ $\left\{\rho, \sigma_{\varepsilon}, \gamma_{\text {Britain }}, \gamma_{\text {France }}, \gamma_{\text {Italy }}, \gamma_{\text {Germany }}, \gamma_{\text {Austria }}, d_{\text {Britain }}, d_{\text {France }}, d_{\text {Italy }}, d_{\text {Germany }}, d_{\text {Austria }}, \sqrt{r_{\text {Britain }}}, \sqrt{r_{\text {France }}}, \sqrt{r_{\text {Italy }}}, \sqrt{r_{\text {Germany }}}, \sqrt{r_{\text {Austria }}}\right\}$.

Parameter estimates are computed by maximizing the normal likelihood function with respect to the vector $\theta$ using the time-varying Kalman filter. This estimation procedure is discussed in more detail in Anderson, Hansen, McGrattan and Sargent (1996). The advantage of this estimation technique is that conditional on the parameter estimates, the Kalman filter produces one-sided estimates of $f_{t}$ and $z_{t}$. I argue in the next section that I can attach economic interpretations to these two series.

To derive the likelihood function, define ${ }^{-} y \equiv y_{+1}-D y_{t}$ and $\bar{G} \equiv G A-D G$ so equations (1)-(4) can be rewritten as:

$$
\begin{aligned}
x_{t+1} & =A x_{t}+C w_{t+1} \\
\bar{y} & =\bar{G} x_{t}+G w_{t+1}+\eta_{t+1} .
\end{aligned}
$$


where $x_{t}=\left[z_{t}, f_{t}, f_{t-1}\right]^{\prime}, w_{t+1}=\left[\vartheta_{t+1}, \varepsilon_{t+1}\right]$ and

$$
A=\left[\begin{array}{rrr}
\rho & 0 & 0 \\
0 & 2 & -1 \\
0 & 1 & 0
\end{array}\right], \quad C=\left[\begin{array}{cc}
1 & 0 \\
0 & \sigma_{\varepsilon} \\
0 & 0
\end{array}\right], \text { and } \quad G=\left[\begin{array}{lll}
\gamma_{\text {Britain }} & 1 & 0 \\
\gamma_{\text {France }} & 1 & 0 \\
\gamma_{\text {Italy }} & 1 & 0 \\
\gamma_{\text {Germany }} & 1 & 0 \\
\gamma_{\text {Austria }} & 1 & 0
\end{array}\right]
$$

Next, let $\hat{E}[Y \mid X]$ denote the linear least squares projection of $Y$ onto $X$, and let $K_{t}$ and $\Sigma_{t}$ denote the time $t$ 'Kalman gain' and 'state-covariance matrix,' respectively, of the time-varying Kalman filter. So, $K_{t}$ and $\Sigma_{t}$ satisfy: $\left.K_{t}=C C^{\prime} G^{\prime}+A \Sigma_{t} \bar{G}^{\prime}\right)\left(\bar{G} \Sigma_{t} \bar{G}^{\prime}+R+G C C^{\prime} G^{\prime}\right)^{-1}$ and $\Sigma_{t}=A \Sigma_{t-1} A^{\prime}+C C^{\prime}-\left(C C^{\prime} G^{\prime}+\right.$ $\left.A \Sigma_{t-1} \bar{G}^{\prime}\right)\left(\bar{G} \Sigma_{t-1} \bar{G}^{\prime}+R+G C C^{\prime} G^{\prime}\right)^{-1}\left(\bar{G} \Sigma_{t-1} A^{\prime}+G C C^{\prime}\right)$. I then apply the Kalman filter to equations (5) and (6) to obtain the corresponding innovations representation:

$$
\begin{aligned}
\hat{x}_{t+1} & =\rho \hat{x}_{t}+K_{t} u_{t} \\
\bar{y} & =\bar{G} \hat{x}_{t}+u_{t}
\end{aligned}
$$

where $u_{t}=y_{t+1}-\hat{E}\left[y_{t+1} \mid y_{t}, \ldots, y_{1}, \hat{x}_{1}\right], \hat{x}_{t}=\hat{E}\left[x_{t} \mid y_{t}, \ldots, y_{1}, \hat{x}_{1}\right]$ and $E u_{t} u_{t}^{\prime} \equiv \Omega_{t}=\bar{G} \Sigma_{t} \bar{G}^{\prime}+R+G^{\prime} \bar{G}$. The Gaussian log-likelihood function for $\left\{y_{t}\right\}_{t=1}^{T}$ conditioned on $\hat{x}_{1}$ is given by:

$$
\log L(\theta)=-(T-1) \log 2 \pi p-\frac{1}{2} \sum_{t=1}^{T-1} \log \left|\Omega_{t}\right|-\frac{1}{2} \sum_{t=1}^{T-1} u_{t}^{\prime} \Omega_{t}^{-1} u_{t}
$$

I initialize the system by setting $\hat{z}_{1}$ equal to zero (its unconditional mean), $f_{1}=f_{0}=\frac{1}{5} \sum_{i}\left(y_{1}^{i}\right)$, and $\Sigma_{1}$ equal to a matrix of large numbers. These choices implies $v_{1}^{i}$ is set to $y_{1}^{i}-f_{1}$.

\section{Model Estimation and Diagnostics}

The point estimates and standard errors of the parameters for both the five-country monthly model and the three-country daily model are reported in table 2 . For both models, the coefficients on the common factor for the Allies $\left(\gamma_{\text {Britain }}, \gamma_{\text {France }}\right.$, and $\left.\gamma_{\text {Italy }}\right)$ are of opposite sign to the Central Powers $\left(\gamma_{\text {Germany }}\right.$ and $\left.\gamma_{\text {Austria }}\right)$. The common factor operates symmetrically on the two sides' currencies. Since the point estimates for the $\gamma$ 's for the Allies have a positive sign, increases in $z_{t}$ can be interpreted as increasing perceptions that the Allies would win the war. Each of the point estimates of $\gamma_{i}$ are more than two standard errors away from zero. For the five-country model, the parameter estimates for Great Britain and France are quite similar. This is not surprising since the sterling-franc exchange rate was pegged from April 1916 to the end of the war. I re-estimated each model, individually omitting Britain and France, and found the results did not 


\begin{tabular}{|c|c|c|c|c|}
\hline & \multicolumn{2}{|c|}{$\begin{array}{c}\text { Five-Country } \\
\text { Monthly Model }\end{array}$} & \multicolumn{2}{|c|}{$\begin{array}{c}\text { Three-Country } \\
\text { Daily Model }\end{array}$} \\
\hline Parameter & $\begin{array}{c}\text { Point } \\
\text { Estimate }\end{array}$ & $\begin{array}{l}\text { Standard } \\
\text { Error }\end{array}$ & $\begin{array}{c}\text { Point } \\
\text { Estimate }\end{array}$ & $\begin{array}{l}\text { Standard } \\
\text { Error }\end{array}$ \\
\hline$\rho$ & 0.93 & 0.09 & $1.00^{\dagger}$ & \\
\hline$\sigma_{\varepsilon}$ & 0.21 & 0.04 & 0.0150 & 0.0004 \\
\hline$\gamma_{\text {Britain }}$ & 0.19 & 0.05 & 0.0468 & 0.0023 \\
\hline$\gamma_{\text {France }}$ & 0.21 & 0.05 & 0.0367 & 0.0027 \\
\hline$\gamma_{\text {Italy }}$ & 0.13 & 0.03 & & \\
\hline$\gamma_{\text {Germany }}$ & -0.09 & 0.04 & -0.0066 & 0.0008 \\
\hline$\gamma_{\text {Austria }}$ & -0.10 & 0.05 & & \\
\hline$d_{\text {Britain }}$ & 0.96 & 0.05 & 0.530 & 0.085 \\
\hline$d_{\text {France }}$ & 0.92 & 0.11 & 0.990 & 0.005 \\
\hline$d_{\text {Italy }}$ & 0.86 & 0.12 & & \\
\hline$d_{\text {Germany }}$ & 0.68 & 0.22 & 0.450 & 0.055 \\
\hline$d_{\text {Austria }}$ & -0.26 & 0.36 & & \\
\hline$\sqrt{r_{\text {Britain }}}$ & 0.091 & 0.021 & 0.036 & 0.021 \\
\hline$\sqrt{r_{\text {France }}}$ & 0.003 & 0.547 & 0.060 & 0.001 \\
\hline$\sqrt{r_{\text {Italy }}}$ & 0.134 & 0.026 & & \\
\hline$\sqrt{\sqrt{r_{\text {Germany }}}}$ & 0.123 & 0.019 & 0.015 & 0.001 \\
\hline$\sqrt{r_{\text {Austria }}}$ & 0.072 & 0.023 & & \\
\hline number of observations & & & & \\
\hline $\begin{array}{c}\text { value of the } \\
\text { log-likelihood }\end{array}$ & & & & \\
\hline
\end{tabular}

Table 2: Estimation results

$\dagger$ For the daily model, the value of $\rho$ was fixed to one prior to estimation.

change in any interesting way. Thus for both the monthly and daily data, I just report the cases including both Britain and France.

The likelihood function was derived assuming the innovations, $u_{t}$, are white noise. As a check I regressed each innovations series, $\left\{u_{t}^{i}\right\}$ where $i=\{$ Britain, France, Italy, Germany, Austria $\}$, on a constant and one lag of the innovation. For all the series in both models the constant term was not significantly different than zero at the 5 percent level. But for two series in the daily model (Britain and France) the coefficients on the lag innovation are significantly different from zero at the 5 percent level.

The decomposition of the exchange rates into three uncorrelated factors $\left(f_{t}, z_{t}\right.$, and $\left.v_{t}\right)$ is similar to principal component analysis. Principal component analysis involves transforming the normalized exchange rates into score vectors. These vectors are pairwise-uncorrelated, linear combinations of the original data; the first series has the maximum possible variance under the constraint that the sum of squares of the co- 


\begin{tabular}{||c|c|c|c|c|c|c||}
\hline \multirow{2}{*}{ series } & $\begin{array}{c}\text { variance } \\
y_{t}^{i}-f_{t} \\
(1)\end{array}$ & $\begin{array}{c}\text { variance } \\
\gamma_{i} z_{t}+v_{t}^{i} \\
(2)\end{array}$ & $\begin{array}{c}\text { Column (1)/ } \\
\text { Column (2) } \\
(3)\end{array}$ & $\begin{array}{c}\text { variance } \\
\gamma_{i} z_{t} \\
(4)\end{array}$ & $\begin{array}{c}\text { variance } \\
v_{t}^{i} \\
(5)\end{array}$ & $\begin{array}{c}\text { Column (4)/ } \\
\text { Column (2) } \\
(6)\end{array}$ \\
\hline Britain & 0.341 & 0.360 & 0.95 & 0.253 & 0.107 & 0.70 \\
\hline France & 0.165 & 0.310 & 0.53 & 0.310 & 0.000 & 1.00 \\
\hline Italy & 0.172 & 0.188 & 0.91 & 0.118 & 0.071 & 0.62 \\
\hline Germany & 0.070 & 0.081 & 0.86 & 0.053 & 0.028 & 0.65 \\
\hline Austria-Hungary & 0.048 & 0.070 & 0.69 & 0.064 & 0.006 & 0.92 \\
\hline
\end{tabular}

Table 3: Variance decomposition for the five-country monthly model

efficients is one, the second has the maximum possible variance among those uncorrelated with the first (again under the constraint that sum of squares of the coefficients is one), and so on. ${ }^{7}$ Unlike the factor model described in equations (1)-(4), principal component analysis imposes no temporal structure on the scores. To ensure that the factors $f_{t}$ and $z_{t}$ extracted from the filtering problem are not just artifacts of the assumptions made in these four equations, I compare the linear one-step-ahead forecasts of $f_{t}$ and $z_{t}$ (denoted $\hat{f}_{t}$ and $\hat{z}_{t}$ ) to the first two principal components of the normalized exchange rates.

In figures $3,4,5$, and 6, I plot the one-step-ahead forecasts of $f_{t}$ and $z_{t}$ along with the first and second principal components of the exchange rates for the monthly and daily models. For both datasets, the first principal component is effectively two times the simple arithmetic average of the normalized series. In the case of the five-country model, the first and second principal components move closely with $\hat{f}_{t}$ and $\hat{z}_{t}$ over the sample period; the correlation between the $\hat{f}_{t}$ and the first principal component is 0.98 . Since $\hat{z}_{t}$ is initialized at zero while the second principal component is unconstrained, these two series differ during the first part of the sample; nevertheless the correlation between the two series is still quite high, 0.88 .

For the three-country model, $\hat{z}_{t}$ is similar to the second principal component; the correlation coefficient for the two series is 0.96 . But the paths of $\hat{f}_{t}$ and the first principal component differ considerably in 1917 and 1918. Comparing figures 2 and 6 it is clear that $\hat{f}_{t}$ tracks the German-Swiss exchange rate; thus it is not surprising the point estimate of $\gamma_{\text {Germany }}$ is so small (-0.0066). In the daily model, movements in the German exchange rate are largely explained by movements in $f_{t}$. This result is robust to numerous specifications of the daily model. Consequently in the next section much of the interpretations of $\hat{f}_{t}$ and $\hat{z}_{t}$ focus on the monthly model.

In table 3 the unconditional variance of the "detrended" one-step-ahead forecast for each exchange rate

\footnotetext{
${ }^{7}$ For further discussion of principal component analysis, see chapter 11 of Anderson (1984).
} 


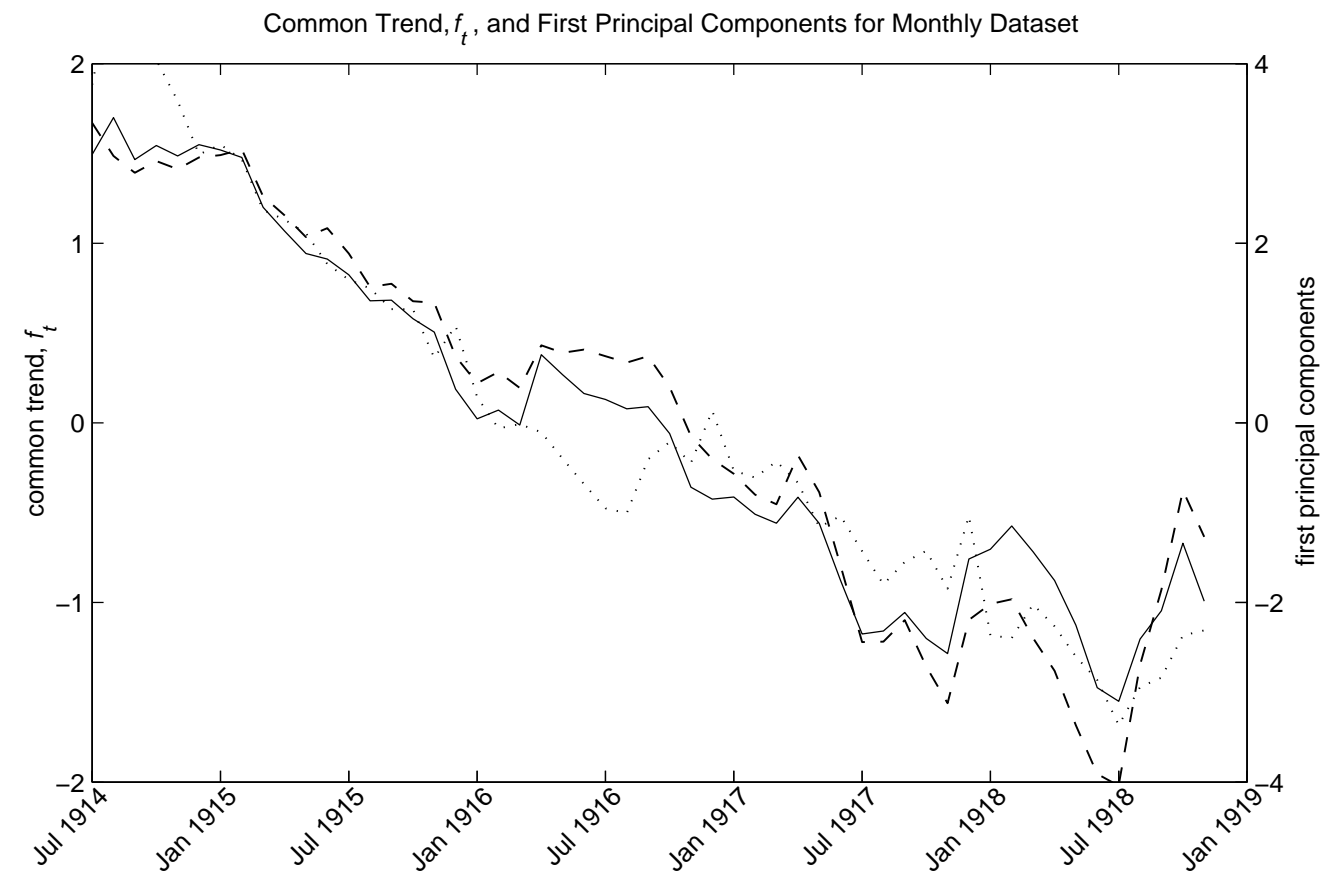

Figure 3: The one-step-ahead forecast of the common trend, $\hat{f}_{t}$, (solid line, left axis) for the five-country model, first principal component of the monthly exchange rates (dashed line, right axis), and first principal component of the notes in circulation (dotted line, right axis).

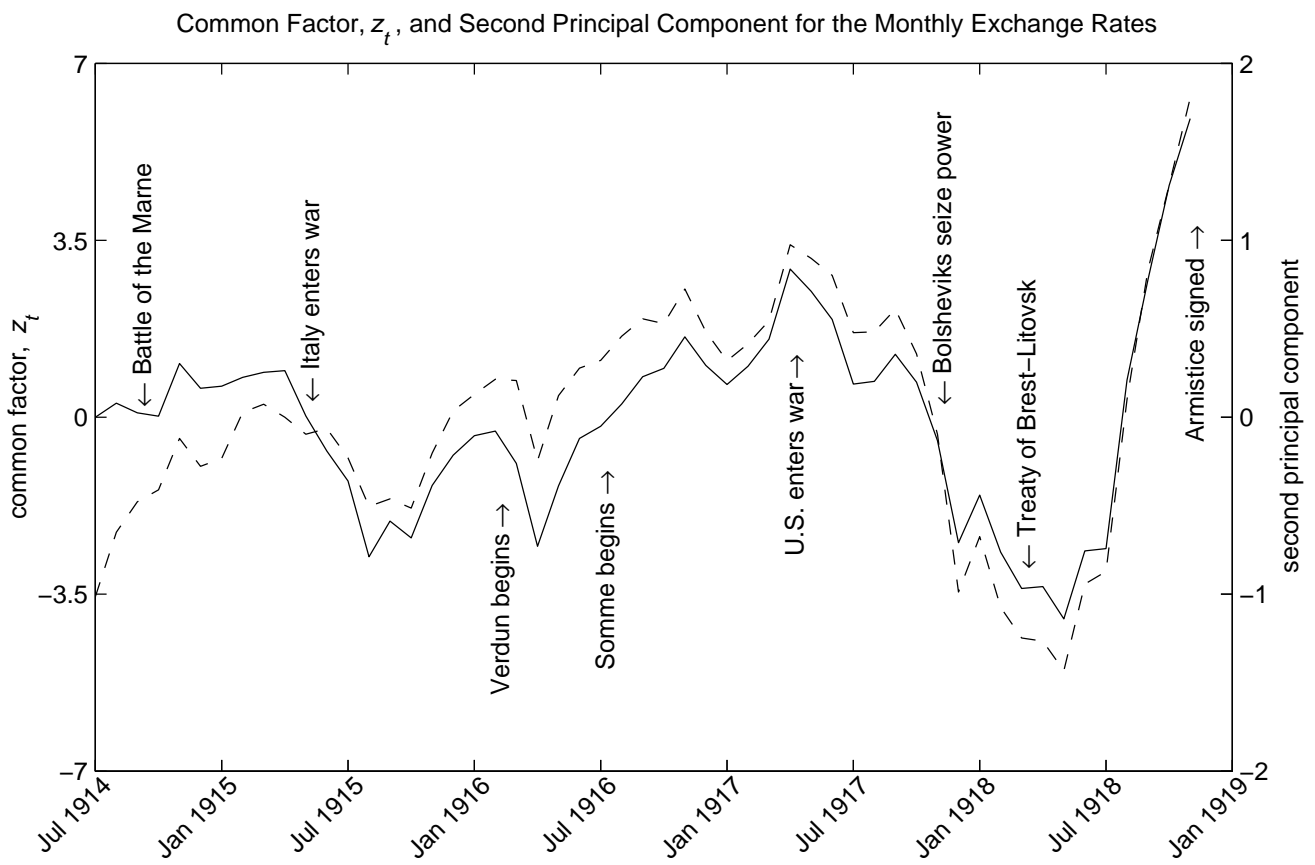

Figure 4: The one-step-ahead forecast of the common factor, $\hat{z}_{t}$, (solid line, left axis) and the second principal component (dashed line, right axis) for the five-country monthly model. 


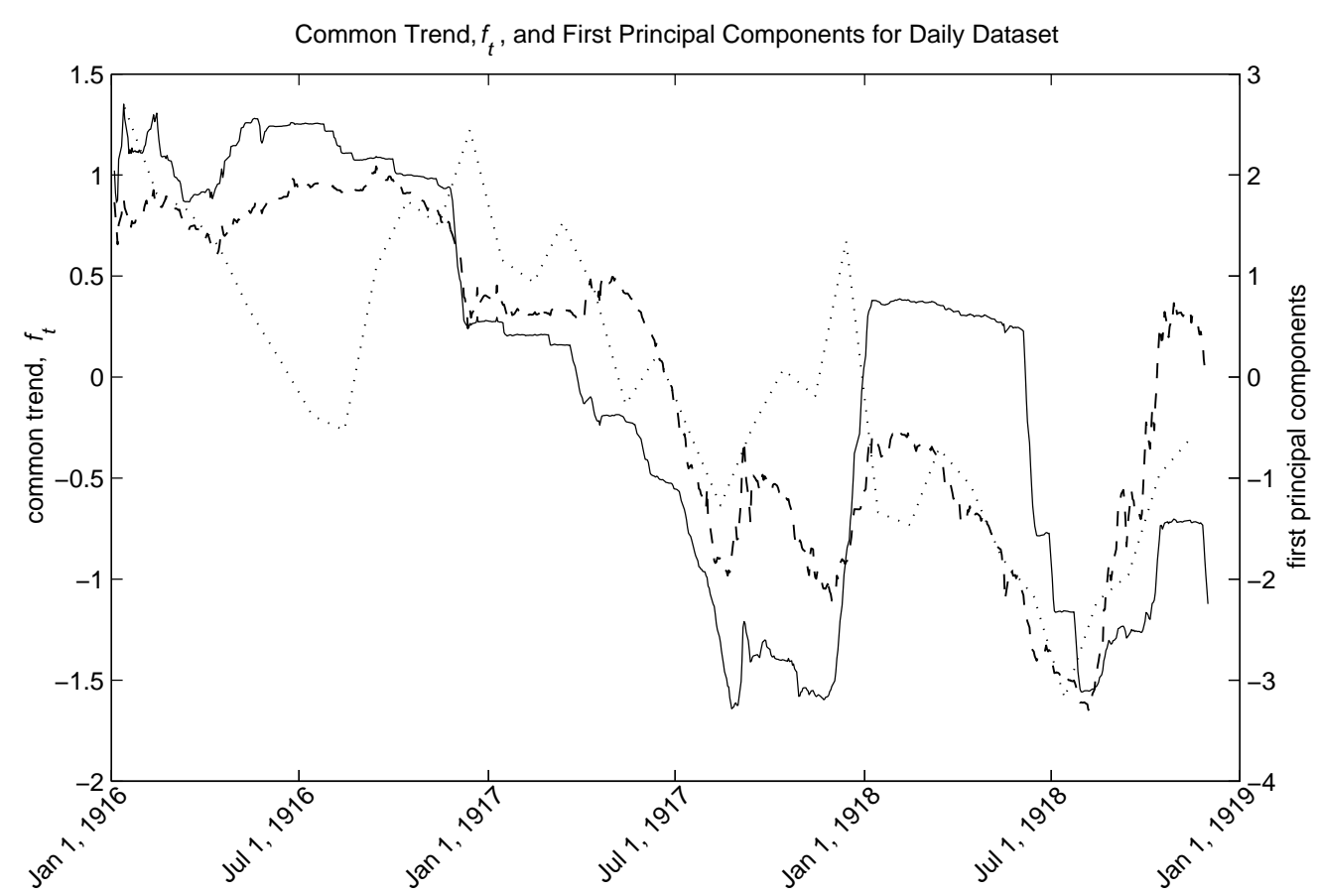

Figure 5: The one-step-ahead forecast of the common trend, $\hat{f}_{t}$, (solid line, left axis) for the three-country model, first principal component of the monthly exchange rates (dashed line, right axis), and first principal component of the notes in circulation (dotted line, right axis).

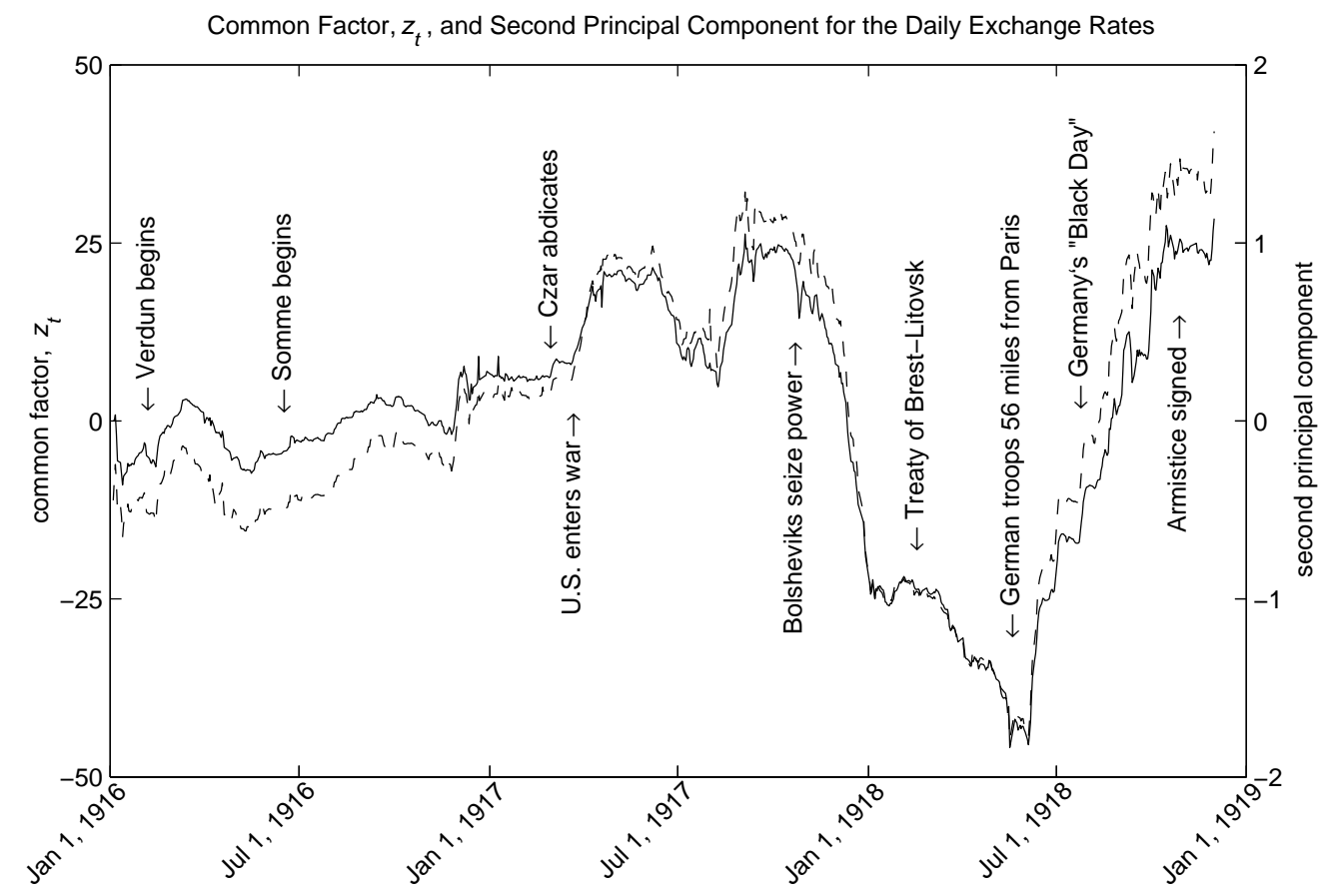

Figure 6: The one-step-ahead forecast of the common factor, $\hat{z}_{t}$, (solid line, left axis) and the second principal component (dashed line, right axis) for the three-country daily model. 
is decomposed into the fraction due to the single common factor and the fraction due to the country-specific factor. From equation (1) we can derive

$$
\operatorname{var}\left(y^{i}-f\right)=\gamma_{i} \operatorname{var}(z) \gamma_{i}^{\prime}+\operatorname{var}\left(v^{i}\right)
$$

where $\operatorname{var}(z)=\sum_{j=0}^{\infty}\left(\rho^{j}\right)^{2}$ and $\operatorname{var}\left(v^{i}\right)=\sum_{j=0}^{\infty} d_{i}{ }^{j} r_{i} d_{i}{ }^{j}{ }^{8}$ In columns (1) - (3) of table 3, I compare the variance of $y_{t}^{i}-f_{t}$ (the detrended exchange rates) to the unconditional variance of $\gamma_{i} z_{t}+v_{t}^{i}$. This is one measure of how well the model fits the data. Ideally these two numbers should be equal (i.e. the numbers in column (3) should be 1). The five-country model does a reasonably good job matching the second moments of the data for Britain, Italy and Germany, but does less well for France and Austria-Hungary.

A similar variance decomposition can be done using the score vectors derived from the principal component analysis. I can compute the proportion of the variance of the normalized exchange rates left unexplained by the first principal component that is explained by the second principal component. For the monthly data, the second principal component explains 68 percent of the residual variance for Britain, 55 percent for France, 59 percent for Italy, 95 percent for Austria-Hungary, and 95 percent for Germany. For the daily data, these numbers are 77 percent for Britain, 92 percent for France, and 100 percent for Germany. For both sets of exchange rates, the second principal component explains a large fraction of the residual variance.

I also use equation (10) to decompose the variance of $\gamma_{i} z_{t}+v_{t}^{i}$ into the variance implied by the common factor (the fourth data column of table 3 ) and the variance implied by the country-specific factor (the fifth data column). For the five-country model, the common factor explains about $2 / 3$ of the total variance for Britain, Italy and Germany, and over 90 percent of the variance for France and Austria-Hungary. A large fraction of the variance of each of the detrended exchange rates $\left(y_{t}-f_{t}\right)$ can be accounted for by a single factor. In other words, once the trend in taken into account, a large fraction of the exchange rate movements arise solely from movements in $\hat{z}_{t}$.

\section{$5 \quad$ Interpreting the $\hat{f}_{t}$ and $\hat{z}_{t}$ series}

In this section, I ask whether an economic interpretation can be given to $\hat{f}_{t}$ and $\hat{z}_{t}$. Since the $\hat{f}_{t}$ series, plotted in figures 3 and 5, are essentially picking up the long downward trend in the exchange rates, I investigate whether a "quantity theory of money" explanation makes sense. I also analyze whether movements in the $\hat{z}_{t}$ series, plotted in figures 4 and 6 , and its innovations (which I will refer to as $K_{t} u_{t}(1)$ ),

\footnotetext{
${ }^{8}$ I am unable to perform this decomposition for the daily model since I fixed $\rho=1$.
} 
correspond to well known historical events - in particular, events which led people to adjust their forecasts of the outcome of the war. However, just as the Wall Street Journal can "explain" every movement in yesterday's stock market, I can always find some event to explain every movement in the $\hat{z}_{t}$ series. Therefore I study whether the $\hat{z}_{t}$ series and its innovations $K_{t} u_{t}(1)$ are correlated with monthly data on casualties from the Western Front, food consumption in Germany and Great Britain, and British shipping losses.

In every European country for which I have data there were large increases in both note circulation and other credits during the war. This led to sharp increases in prices throughout Europe. To determine how much of the relative movements in exchange rates are due to the relative increases in government obligations, I study the quantity of notes in circulation issued by the central banks for each of the belligerents. ${ }^{9}$ I divide each of these series by the total notes in circulation issued by the Swiss National Bank. ${ }^{10}$ As with the exchange rate data, I normalize each series to have a mean of zero and a standard deviation of one. I then compute the principal components for these series.

For the monthly dataset, the first principal component of the five normalized note series is the dotted line plotted in figure 3. It is highly correlated with the both the first principal component of the monthly exchange rates and the $\hat{f}_{t}$ series. The correlation coefficients are 0.92 and 0.95 respectively. This suggests that much of the decline in the value of belligerent currencies relative to the Swiss franc can be attributed to the relative increases in the quantity of central bank notes outstanding. The remaining four principal components from the notes series are much less correlated with the remaining four principal components for the exchange rate series. The correlation coefficient between the second principal component of the note series and the second principal component of the exchange rate series is 0.08 ; for the third, fourth, and fifth principal components the correlation coefficients are $-0.003,-0.09,0.04$ respectively. While both the money series and the exchange rate series have similar trends, the other components are unrelated.

In figure 5 I plot the first principal component of the three normalized note series (Britain, France, and Germany) along with the first principal component and $\hat{f}_{t}$ series for the daily dataset. All three series appear to move together at low frequencies but do not appear to co-move at high frequencies. To compute correlations between the series I point sampled the daily data on the mid-date (i.e. usually the 15th) of each month. The correlation coefficients between the first principal component of the note series and the first principal component of the exchange rate series is 0.73 ; the correlation with the $\hat{f}$ series is only 0.55 .

\footnotetext{
${ }^{9}$ These data are taken from Young (1925). While central bank notes in circulation is a very narrow measure of money, it is the only consistent monthly money series I could construct across all six countries.

${ }^{10}$ So, for example, the British series is Bank of England notes outstanding (in pounds) divided by Swiss National Bank notes outstanding (in francs).
} 
For both models, the one-step-ahead forecast of the common factor, $\hat{z}_{t}$, plotted in figures 4 and 6 , makes intuitive sense. In the monthly model, the $\hat{z}_{t}$ series reaches its global maximum in November 1918, the month of the signing of the Armistice. The second highest peak is April 1917, the month the U.S. declared war against Germany. It hits its nadir in May 1918, during the middle of the Germans' last attempt to win the war. The largest negative innovation occurs in November 1917 - the month the Bolsheviks under Lenin seized power in Russia and immediately opened peace negotiations with Germany. Four of the largest seven negative innovations are in late 1917 and early 1918. These were months in which there were plenty of good reasons for the Allies to be pessimistic: it had become clear the Russians were pulling out of the war and thus the Germans would be able to concentrate more men and weapons on the Western Front; Italy had been routed in October 1917 at the Battle of Caporetto; and Serbia and Romania had been defeated. Like the monthly model, the $\hat{z}_{t}$ for the daily model reaches its zenith in November 1918 and its nadir in May 1918. But the timing of some of the other "peaks" differ. In particular, the second highest peak in the daily model occurs in September 1917.

During the first year of the war there is little movement in the monthly $\hat{z}_{t}$ series; it is essentially flat for the first twelve months. During this period there is a modest upward trend in the second principal component. This discrepancy between the two series is partly due to how the Kalman filter is initialized. Recall I initialized $\hat{z}_{1}=0$. The second principal component is picking up the sharp appreciation of the British pound that is apparent in figure 1. After the outbreak of hostilities and the belligerents' decision to suspend convertibility, most of the belligerents' currencies rose slightly and traded above par as the belligerents attempted to quickly raise resources. This appreciation was more pronounced for the pound than for other currencies. It appears that the appreciation in the second principal component during this second half of 1914 is due more to the intense demand for funds in London than to battlefield news.

Italy's entrance into the war on the Allied side in May of 1915 seems to have had a negative effect on the monthly $\hat{z}_{t}$ series. Italy may have been perceived as much of a liability as an asset. The Italian Army was poorly equipped having not fully recovered from the Libyan War of 1912. Between their equipment problems and the line of mountains between Italy and Austria, the Italian were of little use in forcing Germany to send forces to the Southern Front. Furthermore, the British were already having to export coal to France since nearly all of the coal mines in north-eastern France were behind enemy lines; now the British were having to supply the Italians as well.

Despite being two of the bloodiest battles of the war, neither the German attack on the French fort at Verdun nor the British offensive at the Somme had much effect on the $\hat{z}_{t}$ series for either model. The 
German attack on Verdun from February to June 1916 was an attempt to deal France a psychological blow as well as to force France to incur great losses in men and equipment. While German armies did succeed in inflicting a large number of casualties on the French (over 500,000 men), German losses were also huge (over 400,000 men) and the fort remained in French hands. The British attack at the Somme generated shockingly long casualty lists but little gains in terms of territory for either side. As is well known, on the first day of the Battle of Somme, July 1, 1916, the attacking British army suffered over 60,000 casualties (of which about 20,000 were fatalities) while German casualties were only about 8,000. Verdun and the Somme had a large effect on the morale of all three armies. The heavy German casualties contributed to the Kaiser's decision to replace Falkenhayn with Hindenburg as Chief of the General Staff. Dupuy and Hammerman (1967) state these two battles also brought home to Germany the possibility of defeat. While some argue that German morale never fully recovered from the combined impact of theses two battles, British and French morale also suffered forcing the French General Joffre to resign.

While the monthly $\hat{z}_{t}$ series fell in early 1916 with large negative innovation in February and March (coinciding with the start of the Battle of Verdun), somewhat surprisingly the $\hat{z}_{t}$ series becomes positive and continued to rise during the remainder of 1916 despite the large British losses at the Somme. In the daily model there are no large innovations (either positive or negative) from February to December 1916. There is no evidence of either of Verdun or the Somme in the daily data.

In both models, the $\hat{z}_{t}$ series peaks in April of 1917, the month the U.S. declared war of Germany, and one month after the Russian revolution. On March 12, 1917 the Russian Revolution began and within days the Czar was forced to abdicate his throne. Taylor (1980) states that the Russian Revolution was "hailed with great rejoicing" by the West. According to Taylor, the West thought that the revolution would only make the Russian Army stronger. In the monthly model, the fourth largest positive innovation occurs in March of 1917. With monthly data I cannot disentangle whether this large innovation was due to the Russian Revolution or anticipation of the American entrance into the war; but with daily data, it appears that while the start of the Russian revolution generated a small relative increase in the value of the Allies' currencies, the entrance of the U.S. into the war generated a large boost. This sixth largest innovation occurs on April 5, 1917, the day before the U.S. declared war on Germany. The Unites States' declaration of war also had a negative impact on the "common trend" $\hat{f}_{t}$ in the daily model. ${ }^{11}$ On the sixteen business days following the declaration, there are twelve negative innovations on $f_{t}$.

In the last two years of the war, the relative value of the exchange rates move dramatically. After April

\footnotetext{
${ }^{11}$ Recall that in the daily model, $\hat{f}_{t}$, basically track the German-Swiss exchange rate.
} 
1917 the $\hat{z}_{t}$ series and the second principal component for the monthly model drop sharply and decline steadily throughout 1917 as a series of bad news hit the Allies. A large mutiny in the French army from May to August limited French military capabilities. In October and November of 1917, the Italian Army suffered one of its largest defeats in the Battle of Caporetto. The outcome of this battle led to a substantial depreciation of the lira. This shows up as large negative innovations for the Italian exchange rate $u_{t}^{\text {Italy }}$ from September 1917 to January 1918. Military successes and the utilization of credits from the U.S. and Britain in the summer and fall of 1918 led to increases in the lira's relative value.

As mentioned above, large negative innovations occur in late 1917 in particular in the months of October and November. In November of 1917 the Bolsheviks seized power in Petrograd and the Congress of Soviets called for peace. Ferguson (1998, pages 333-336) reports that prices in New York for the 1915 Anglo-French 5 per cent coupon bonds fell dramatically in late 1917, hitting a nadir in December. Prices for these bonds recovered steadily throughout 1918. Ferguson states "The surprising thing is that the New York market remained so bullish about the Anglo-French bonds the following spring when many influential figures in Britain and France sincerely feared Germany was on the brink of victory." Using monthly Swiss exchange rates, the story is a little different. While the $\hat{z}_{t}$ series drops to -2.5 in December it rebounds slightly to -1.5 in January 1918 before steadily declining to a nadir of -4.0 in May 1918. A similar pattern can be seen in the daily data. So the movements in the Swiss foreign exchange market in early 1918 are less surprising and more consistent with the perceived mood of "many influential figures in Britain and France" than the New York bond market; however these declines in the $\hat{z}_{t}$ series make the rise in bond prices all the more puzzling.

Furthermore, all the belligerent currencies rose in value at the end of 1917 and start of 1918. This can be seen directly in the exchange rate data in figures 1 and 2, or in the common trends in figures 3 and 5. Not only were the Bolsheviks calling for peace at this time, but President Woodrow Wilson outlined his fourteen points in January of 1918 and called for a peace without reparations in February of 1918. This parallel increase in currency values is consistent with the idea that these calls led currency traders to decrease their expectations about the war's duration. However these peace proposals were rejected by Britain, France, and Germany. Furthermore the collapse of Russia and these calls for peace appear to have led Germany to harden its negotiation position, thus increasing the expected length of the war. This uniform increase in currency values was short lived.

The collapse of Russia also permitted the transfer of German troops to the Western Front, giving the Germans numerical superiority. The Germans planned a final effort to win in France before the United 
States could intervene. At the end of March 1918 the Germans began a final offensive. The Germans were able to split the French and British line and by June 3 were only fifty-six miles from Paris. Even though the German advance was not stopped until July, in both models the $\hat{z}_{t}$ series turns in May. After the war Ludendorff, the commanding general of the Germany Army, referred to August 8, 1918 as "the black day of the German Army." Ludendorff felt that a relatively minor Allied victory on this date finally shattered the German Army's faith in any potential victory. The two $\hat{z}_{t}$ series suggests that the currency markets foresaw this "black day" months earlier.

While this informal review suggests military events are important in describing the movements of exchange rates, I recognize that I can always find some event that explains every movement in each of the five exchange rates. Therefore I restrict myself by comparing the $\hat{z}_{t}$ series to military data on the progress of the war. The best battlefield data I could find are on casualties.

The data I have on British and German casualties are taken from the War Office (1922). ${ }^{12}$ I obtained data on French casualties from Larcher (1934). ${ }^{13}$ I was unable to get times series data on American casualties. I focus on the Western Front for two reasons. First, I was unable to get any reliable military data on either the Southern or Eastern Fronts. Second, most historians I have read argue that winning on the Western Front was the key to winning the war. ${ }^{14}$ Indeed the Germans won the Eastern Front defeating Russia, Romania, and Serbia but lost the war.

Reported casualty statistics are notoriously noisy and at best a rough approximation of the number of military personnel killed, wounded and taken prisoner each month during the war. While casualty data are a crude way to measure military effectiveness, it is not obvious a better metric exists. Offensive capabilities were so inferior to defensive strategies and tactics that neither side could advance fast enough to make a breakthrough. From November 1914 to March 1918 the Western Front was a continuous line of trenches from Switzerland to the North Sea which remained virtually unchanged. Any territorial gains made on either side were negligible and often the result of the other side falling back to positions on better protected ground. Since neither side had much success in capturing territory, both sides implemented a strategy of attrition hoping to wear down or use up the other sides' stock of men. Ferguson (1998, chapter

\footnotetext{
${ }^{12}$ The British data are for the British Expeditionary Force (BEF) in France and include the Regular Army and Territorial Force as well as the armies of Canada, Australia, New Zealand, Newfoundland, South Africa, and India. The German data are originally from the Federal Archives Office at Potsdam. Neither series includes deaths from wounds or disease since these data are not available for the German army. None of the results are sensitive to including deaths from wounds or disease for the BEF.

${ }^{13}$ The French data are from the French Health Service. They are aggregate casualty data, so they include killed, wounded, died from wounds, died from disease and taken prisoner.

${ }^{14}$ See for example Ferguson, 1998, pages 290-292 and the citations contained within.
} 


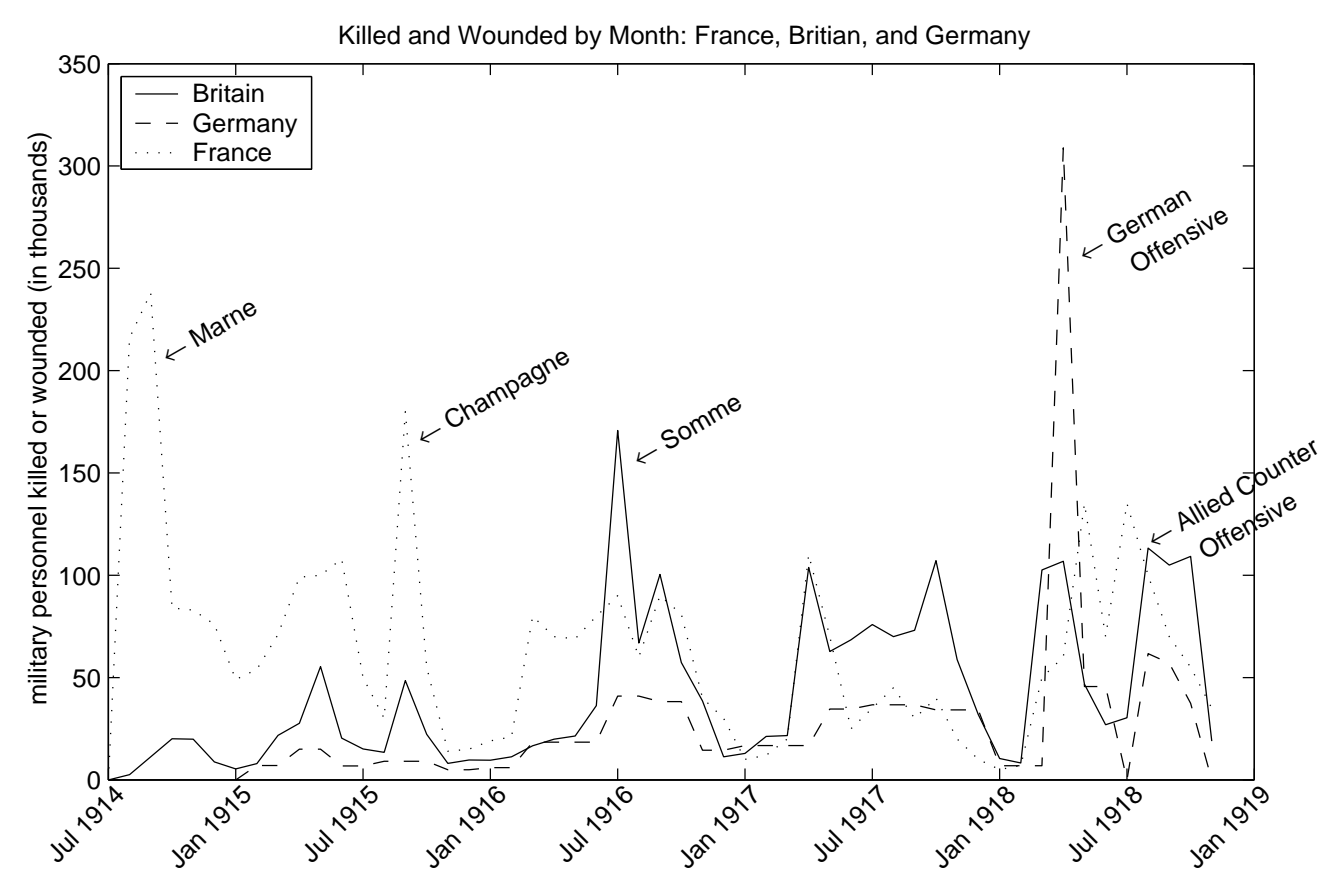

Figure 7: British and German soldiers killed and wounded and French total casualties by month.

10) cites several military leaders expressing the view that the Allied strategy was "to kill as many Germans as possible with the least loss to ourselves." The German Chief of the General Staff Falkenhayn argued for attacking the French fort at Verdun in order "to bleed France white." So data on soldiers incapacitated do provide a metric which contemporaries themselves used to measure combat effectiveness.

As noted by others (i.e. Dupuy, 1977 and Ferguson, 1998), if combat effectiveness is measured by the numbers of men killed and wounded, the Allies failed miserably. In figures 7 and 8 I plot the number of soldiers killed, wounded, and taken prisoner. There are four features of the data I wish to emphasize. The first is the magnitudes on the numbers of killed and wounded each month; in an average month on the Western Front 45,000 British troops and 27,000 German troops were killed and wounded. The French armies absorbed on average 63,000 total casualties per month. These are enormous numbers. Second is the persistent imbalance in German and Allied casualties. Despite losing the war, the Central Powers were far better at inflicting casualties on their enemy than were the Allies. According to the data I have, German soldiers on average killed or wounded over three British soldiers for every two German soldier killed or wounded. Moreover this ratio does not include French and Americans killed and wounded. ${ }^{15}$ Only in the

\footnotetext{
${ }^{15}$ I think this is an overstatement of German military superiority. Dupuy (1977) reports that the German army inflicted on the total Allied force around three casualties for every two that were inflicted on them. I cannot determine the differences between the data I have and the data others report.
} 


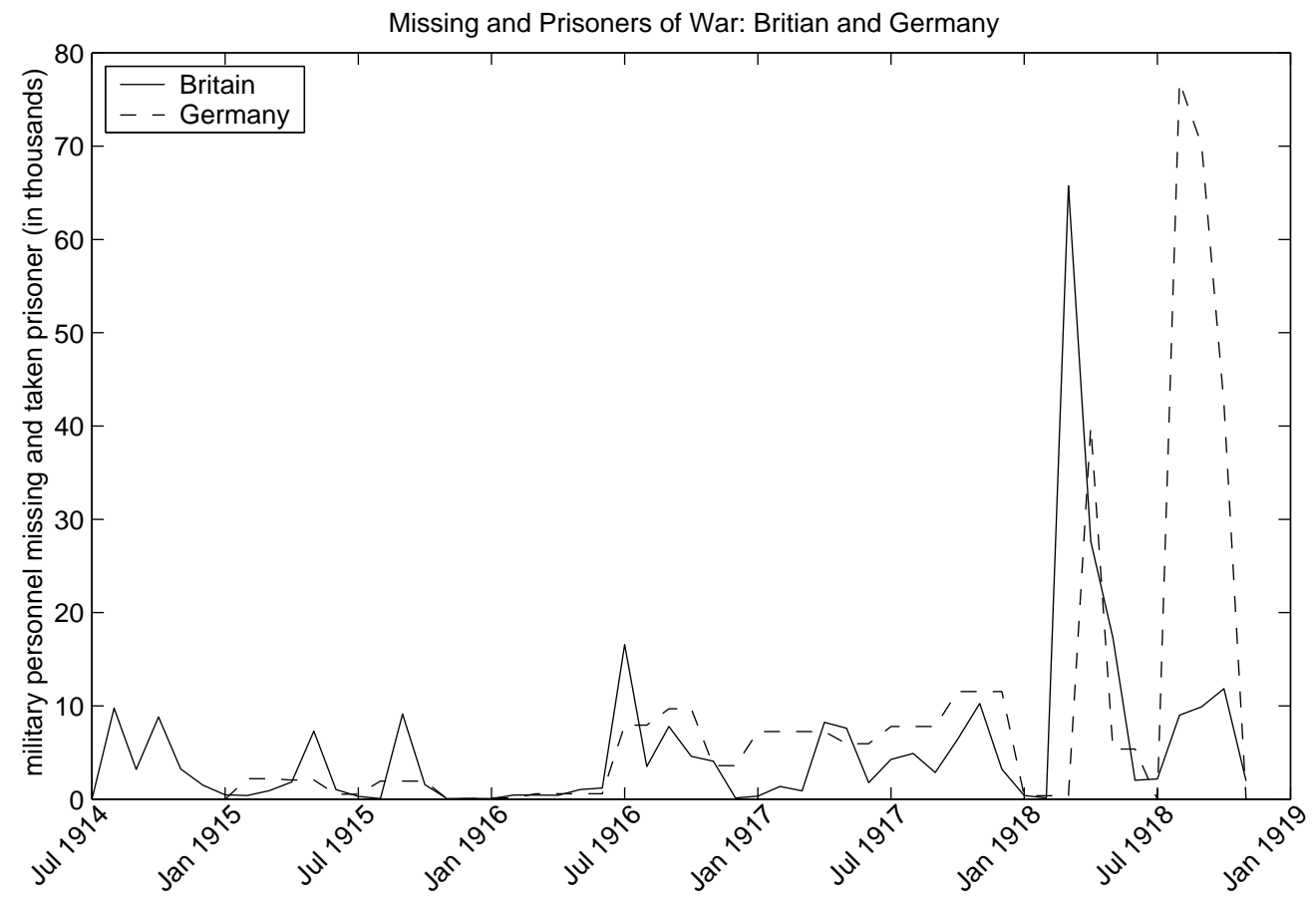

Figure 8: British and German soldiers missing and taken prisoner by month.

Spring of 1918 when the Germans launched their final offensive did they suffer higher casualties than the Allies. Third is the seasonal pattern to the casualty data. Most major battles occurred in the spring and summer months while the winter months were periods of relative calm. I do not see a seasonal pattern in the exchange rate data so any attempt to link casualty data to exchange rate data will not succeed entirely. Fourth is the large increase in the number of soldiers surrendering and being taken prisoner during the last year of the war.

I do not know how quickly market participants learned of events from the battlefield. Both sides kept the press from the front lines and selectively released battlefront news. For example, Dupuy and Hammerman (1967) report that after the French Offensive in Champagne in early October 1915, the Allies publicized their capture of 25,000 prisoners and 150 guns, but kept their casualties - 30,000 killed and missing, 100,000 wounded - a carefully guarded secret to avoid damaging civilian and military morale. For the monthly model, it is not important whether market participants took hours or days to react to news

\footnotetext{
As another illustration of the contradictory nature of casualty data, Gilbert (1994, p 299) states that the death toll at the Somme for the months July-October 1916 was 95,675 for the British, 50,729 for the French, and 164,055 for the Germans. He reports that on November 1, the Allies announced that in the preceding four months, they had taken 72,901 German prisoners and captured 303 artillery pieces, 215 mortars and nearly 1,000 machine guns. He does not cite his source. In contrast to the data I use, these data suggest that more Germans were killed than Allies during the Battle of the Somme. Note that the British and French did not (or Gilbert failed to) report the number of Allied troops taken prisoner.
} 


\begin{tabular}{||l|c|c|c|c|c|c|c||}
\hline & $\begin{array}{c}\text { French } \\
\text { total cas }\end{array}$ & $\begin{array}{c}\text { British } \\
\text { K\&W }\end{array}$ & $\begin{array}{c}\text { German } \\
\text { K\&W }\end{array}$ & $\begin{array}{c}\text { Net Body } \\
\text { Count }\end{array}$ & $\begin{array}{c}\text { British } \\
\text { taken POW }\end{array}$ & $\begin{array}{c}\text { German } \\
\text { taken POW }\end{array}$ & $\begin{array}{c}\text { Net } \\
\text { POWs }\end{array}$ \\
\hline$\hat{z}$ & -0.07 & 0.19 & -0.13 & 0.40 & -0.23 & 0.32 & -0.44 \\
\hline$K_{t} u_{t}$ & 0.13 & 0.11 & -0.05 & 0.16 & -0.01 & 0.39 & -0.37 \\
\hline$u^{\text {Britain }}$ & 0.19 & -0.09 & -0.15 & 0.08 & -0.12 & 0.15 & -0.21 \\
\hline$u^{\text {France }}$ & 0.16 & -0.05 & -0.11 & 0.07 & -0.08 & 0.14 & -0.18 \\
\hline$u^{\text {Italy }}$ & 0.25 & -0.02 & -0.05 & 0.01 & -0.03 & 0.07 & -0.12 \\
\hline$u^{\text {Austria }}$ & -0.09 & -0.15 & -0.04 & -0.12 & -0.05 & -0.26 & 0.22 \\
\hline$u^{\text {Germany }}$ & -0.06 & -0.18 & -0.04 & -0.10 & -0.08 & -0.29 & 0.23 \\
\hline
\end{tabular}

Table 4: Correlation Coefficients between Casualty Data and Series Imputed from the Five-Country Monthly Model

Net body count is the number of British killed and wounded minus the number of Germans killed and wounded.

Net POWs is the number of British taken POW minus the number of Germans taken POW.

from the front, but given the work by Willard, Guinnane, and Rosen (1996) using daily price data from the Civil War, I expect news from the battlefield traveled quickly.

In World War I defensive capabilities were considerably better than offensive tactics and weapons. A handful of well positioned machine guns and a line of barbed wire could hold up a much larger attacking force until reinforcements could be brought in. Thus high casualties were often associated with offensive campaigns. Following Ferguson (1998) I compute a "net body count" by subtracting the number of Germans killed and wounded from the number of British killed and wounded. In table 4 I report the correlation coefficients between the casualty data and various series imputed from the five-country monthly model. The data on soldiers killed and wounded are modestly correlated with the $\hat{z}_{t}$ series and its innovations $K_{t} u_{t}(1)$. For the five-country model, the correlation coefficient between the net body count and $\hat{z}_{t}$ is 0.40 ; the correlation coefficient between the net body count and $K_{t} u_{t}(1)$ is 0.16 . Thus an increase in Allied casualties relative to German casualties is associated with positive innovations to $\hat{z}_{t}$ and higher values of $\hat{z}_{t}$. So a higher net body count is associated with good news for the Allies. This positive relationship between high Allied casualties relative to German casualties and positive innovations to the common factor suggests that being on the offensive was viewed positively by financial markets.

While a higher net body count is associated with positive contemporaneous innovations, the reverse holds true for prisoners of war. As the last three columns of table 4 show, the casualty series most correlated with the series imputed from the factor models is German soldiers taken prisoner. For the five-country model, the correlation coefficient between number of Germans taken prisoner and innovations is 0.39 . The correlation coefficient for net POWs (British taken prisoner minus Germans taken prisoner) the correlation 
coefficient is -0.37 . The correlation between between innovations and lagged net POWs is even greater: -0.57 . This results is largely due to the German POW data. The rate of Germans surrendering is positively correlated with British and French innovations and negatively correlated with German and Austrian innovations. These results are consistent with Ferguson's (1998) thesis that the key to victory in the First World War was not directly due to ones ability to kill the enemy, but rather due to the willingness of soldiers on the other side to surrender. To quote from chapter 13 of Ferguson (1998):

Surrendering was the key to the outcome of the First World War. Despite the huge death rolls, it proved impossible to achieve the ideal objective of pre-war German doctrine, 'annihilation of the enemy': demographics meant that there were more or less enough conscripts each year to plug the gaps created by attrition. For that reason the 'net body count' in the Central Powers' favour was not enough to bring them to victory. However it did prove possible to get the enemy to surrender in such large numbers that his ability to fight was fatally weakened.

People at the time knew that large captures of enemy troops were a good sign. Around 10 percent of the British film The Battle of the Somme is devoted to pictures of German POWs. ... The Germans too produced postcards and newsreels showing foreign prisoners of war being marched through German cities.

This difference between how killed and wounded and POWs were interpreted suggests that the number of POWs taken is highly correlated with morale and the willingness of soldiers to continue fighting. Unlike being killed and wounded, to be taken prisoner often involved a choice. ${ }^{16}$ A soldier could often (but not always) decide whether or not to surrender. This was not usually the case for being killed or wounded. Furthermore, taking an enemy prisoner was arguably better than killing or wounding him. Wounded soldiers were often returned to the front after their injuries healed. Prisoners on the other hand were sources of intelligence and could perform work for the captor. As figure 7 shows even during the last half of 1918, the net body count was still in the German's favor; but as figure 8 illustrates German soldiers were giving up in unprecedented numbers. In terms of killing and wounding, the German army was still more effective than the Allies. (And again note figure 7 does not include the number of American soldiers killed and wounded.) Nevertheless - in terms of prisoners of war - there was no doubt in second half of 1918 that the Germans were losing.

Relative to the Allies, Germany had a more difficult time growing and importing enough food to feed its population during the war. Some have argued that given Germany's success on the battlefield as measured by the net body count, Germany did not lose the war militarily but was starved into defeat. ${ }^{17}$

\footnotetext{
${ }^{16}$ See chapter 13 of Ferguson, 1998, for a nice discussion of the issues surrounding surrendering.

${ }^{17}$ See the first five chapters of Offer, 1989.
} 


\begin{tabular}{||l|c|c|c|c||}
\hline & $\begin{array}{c}\text { German } \\
\text { calorie intake }\end{array}$ & $\begin{array}{c}\text { U.K. meat } \\
\text { consumption }\end{array}$ & $\begin{array}{c}\text { U.K. bread \& } \\
\text { flour consumption }\end{array}$ & $\begin{array}{c}\text { U.K. shipping } \\
\text { losses }\end{array}$ \\
\hline$\hat{z}$ & -0.11 & 0.14 & 0.14 & 0.08 \\
\hline$K_{t} u_{t}(1)$ & -0.53 & -0.31 & 0.09 & -0.04 \\
\hline$u^{\text {Britain }}$ & -0.43 & -0.08 & -0.09 & -0.17 \\
\hline$u^{\text {France }}$ & -0.42 & -0.13 & -0.09 & -0.05 \\
\hline$u^{\text {Italy }}$ & -0.51 & -0.17 & -0.06 & -0.01 \\
\hline$u^{\text {Austria }}$ & 0.11 & 0.20 & -0.13 & -0.06 \\
\hline$u^{\text {Germany }}$ & 0.17 & 0.21 & -0.23 & 0.03 \\
\hline
\end{tabular}

Table 5: Correlation Coefficients between Consumption and Shipping Data and Series Imputed from the Five-Country Factor Model

German calorie intake is the mean daily per capita calorie intake from a set of thirty surveyed households in Leipzig, standardized for age, sex, family size and work performed. The data are monthly from March 1917 to November 1918. Source: Offer (1989) The First World War: An Agrarian Interpretation, page 50.

Consumption of bread and flour in the United Kingdom are monthly index numbers of retailer's sales from June 1916 to November 1918. Source: Beveridge (1928) British Food Control, page 366.

Consumption of butcher's meat in the United Kingdom are monthly index numbers of retailer's sales from January 1916 to November 1918. Source: Beveridge (1928) British Food Control, page 367.

War Losses of British shipping are monthly losses in gross tons from August 1914 to November 1918. Source: Fayle (1927) The War and the Shipping Industry, page 417.

Therefore I examined the average calorie intake from a sample of households in Germany, two measures of food consumption in Britain, and British shipping losses due to the war. In table 5, I report the correlation coefficients between these series and the imputed innovations and $\hat{z}_{t}$ series. German calorie intake is negatively correlated with the innovations implied by the two models. At first glance, it appears that calories were as important as casualties to contemporaries forecasting the duration and outcome of the war; but this result is hard to interpret since German calorie intake is much more correlated with Allied innovations than with German innovations. Furthermore U.K. meat consumption has the same basic correlation pattern as German calorie intake: negatively correlated with Allied innovations, positively correlated with the Central Power's innovations. If currency traders were using data from the home-fronts to adjust their expectations about the war, I cannot explain why these two series would have the same correlation pattern. In contrast, consumption of bread and flour in the U.K. is essentially uncorrelated with all of the imputed series. Finally, U.K. shipping losses are also uncorrelated with all the imputed series. U.K. shipping losses rose steadily during the first half of the war, peaking in early 1917; after this peak, shipping losses steadily declined. This time series pattern does not correspond to the pattern in the innovations or the $\hat{z}_{t}$ series. 


\section{Conclusion}

In this paper I decompose the exchange rate movements for five of the primary European belligerents during World War I into three components: a common trend, $f_{t}$; a common factor, $z_{t}$; and a countryspecific component. Movements in the common trend are consistent with the quantity theory of money.

One-step-ahead forecasts of the common trend, $\hat{f}_{t}$, are highly correlated with a common trend of money stocks. The common factor provides evidence that the value of these currencies also responded predictably to non-monetary events, and in particular to events that help forecast future government surpluses.

Both the casualty and foreign exchange data presented in this paper illustrate that, for the first two and half years, the war was essentially a stalemate. The $\hat{z}_{t}$ series generally oscillated around zero and relatively few prisoners of war were taken. In late 1917 and early 1918 with the collapse of Russia in the Eastern Front, it appeared that Germany had the upper hand. During this period the $\hat{z}_{t}$ series in both models declined steadily, and the number of British taken prisoner relative to the Germans rose dramatically. However as the German's final offensive collapsed in the Summer of 1918 and as U.S. troops began make their presence felt, one can see the tide turning in both $\hat{z}_{t}$ series and the POWs series: $\hat{z}_{t}$ rose sharply and the Germans began to surrender in large numbers.

While these results are consistent with conventional understandings of World War I military history, they are perhaps at odds with modern views of financial markets during the war. It is often argued that the First World War was a time of large government interventions in foreign exchange markets. While there are numerous examples of government attempts to control the value of their currencies, the results presented here demonstrate that these attempts were not entirely successful. During the war all five of the currencies depreciated relative to the Swiss franc despite a doubling of the Swiss price level. Furthermore, as in other wars, currencies of the opposing countries moved in opposite directions in response to military events. 


\section{References}

[1] Anderson, Theodore (1984) An Introduction to Multivariate Statistical Analysis New York: John Wiley and Sons.

[2] Anderson, Evan, Lars Hansen, Ellen McGrattan, and Thomas Sargent (1996) "Mechanics of Forming and Estimating Dynamic Linear Economies," in H. Amman et al., eds. Handbook of Computational Economics, Vol 1, Amsterdam: Elsevier.

[3] Barro, Robert (1979) "On the Determination of the Public Debt," Journal of Political Economy, Vol. 87, (October), pp. 940-971.

[4] Beveridge, William (1928) British Food Control, London: Oxford University Press.

[5] Bogart, Ernest (1921) War Costs and Their Financing, New York: D. Appleton and Company.

[6] Bordo, Michael, and Eugene White (1991) "British and French Finance During the Napoleonic Wars," in Bordo and Capie, eds. Monetary Regimes in Transition, Cambridge, Cambridge University Press.

[7] Bordo, Michael, and Finn Kydland (1995) “The Gold Standard As a Rule: An Essay in Exploration,” Journal of Economic History, Vol. 32, pages 423-464.

[8] Brown, William (1940) The International Gold Standard Reinterpreted, 1914-1934 New York: National Bureau of Economic Research.

[9] Brown, William, and Richard Burdekin (2000) "Turning Points in the U.S. Civil War: A British Perspective," Journal of Economic History, Vol. 60. pages 216-231.

[10] Bulletin de la Statistique General de la France, various issues 1914-1919.

[11] Burnett, Phillip (1965) Reparations at the Paris Peace Conference from the Standpoint of the American Delegation New York: Columbia University Press.

[12] Dupuy, Trevor, and Gay Hammerman (1967) Stalemate in the Trenches: November, 1914 - March, 1918, New York: Franklin Watts, Inc.

[13] Dupuy, Trevor (1977) A Genius for War: The German Army and General Staff, 1807-1945, Englewood Cliffs, NJ: Prentice-Hall Inc. 
[14] Fayle, C. Ernest (1927) The War and the Shipping Industry, London: Oxford University Press.

[15] Federal Reserve Bulletin, Board of Governors of the Federal Reserve System: Washington DC, May $1,1918$.

[16] Federal Reserve Bulletin, Board of Governors of the Federal Reserve System: Washington DC, January, 1920.

[17] Ferguson, Niall (1998) The Pity of War, London: Penguin Press.

[18] Frey, Bruno, and Marcel Kucher (1997) “Bond Values and World War II Events," manuscript, Institute of Empirical Economic Research at the University of Zurich.

[19] Gilbert, Martin (1994) The First World War: A Complete History, New York: Henry Holt and Co.

[20] Kuczynski, R. R. (1923) "German Taxation Policy in the World War," Journal of Political Economy, Vol 31, pages 763-789.

[21] Larcher, Lieutenant-Colonel (1934) "Donnees Statistiques Sur Les Forces Francaises 1914-1918" Revue Militaire Francaise, No 156, (June), pp. 351-363.

[22] McCandless, George (1996) "Money, Expectations, and the Civil War," American Economic Review, Vol. 86, (June), pp. 661-671.

[23] Mitchell, Wesley (1903) A History of the Greenbacks Chicago, IL: The University of Chicago Press.

[24] Offer, Avner (1989) The First World War: An Agrarian Interpretation New York: Oxford University Press.

[25] Roll, Richard (1972) "Interest Rates and Price Expectations During the Civil War," Journal of Economic History, Vol. 32, pages 476-498.

[26] Swiss Bank Corporation (1918) Revue Economique et Financiere Suisse, 1914-1917.

[27] Swiss Bank Corporation (1919) Revue Commerciale et Industrielle Suisse, 1914-1918.

[28] Swiss Bank Corporation (1920) La Situation Economique et Financiere de la Suisse, 1919.

[29] Taylor, A.J.P. (1980) The First World War: An Illustrated History, New York: Perigee Books. 
[30] War Office (1922) Statistics of the Military Effort of the British Empire During the Great War, London: H.M. Stationery Office.

[31] Weidenmier, Marc (1999) Financial Aspects of the American Civil War: War News, Price Risk, and the Processing of Information, unpublished Ph.D. dissertation. University of Illinois.

[32] Willard, Kristen, Timothy Guinnane, and Harvey Rosen (1996) "Turning Points in the Civil War: Views from the Greenback Market," American Economic Review, Vol. 86, pp. 1001-1018.

[33] Young, John (1925) European Currency and Finance, prepared for the United States Senate Commission on Gold and Silver Inquiry, Government Printing Office, Washington DC. 